\title{
Digital Educational Environment, Health Protecting Aspects
}

\author{
Iskandar Sh. Mukhametzyanov* \\ Institute for Strategy of Education Development \\ of the Russian Academy of Education \\ 5/16 Makarenko Str., Moscow, 105062, Russia
}

Received 30.07.2019, received in revised form 26.08.2019, accepted 09.09.2019

The priority project "Modern digital educational environment in the Russian Federation" focuses on widespread introduction of modern ICT into the educational system. At the same time, there is a notable imbalance between the number of students using modern technologies and the number of teachers willing to conduct such training. Only $16 \%$ of teachers are prepared to create and use digital resources for educational purposes. Moreover, only digital environment of educational organization is evaluated, although in digital education actual training also occurs outside of it. We have attempted to assess the current situation based on learning process in high-tech information educational environment, including the educational organization and students' place of residence or stay, since such environment is likely to impact students' health but is also the only environment that enables educational process accounting for health conditions of the students. However, availability of digital educational resources and teachers able to utilize them does not guarantee success. Parents' ability to use technology to oversee educational process and maintain information security / protection of personal data of the student outside the educational institution is essential. Results of the study can serve as basis for development of a program for formation of students' digital educational environment, accounting for contents of the educational organization, students' place of residence and level of information culture of all participants of the learning process.

Keywords: digital educational environment, inclusive education, health-protecting information and educational environment.

Research area: pedagogy.

Citation: Mukhametzyanov, I. Sh. (2019). Digital Educational environment, health protecting aspects. J. Sib. Fed. Univ. Humanit. soc. sci., 12(9), 1670-1681. DOI: 10.17516/1997-1370 0484.

(C) Siberian Federal University. All rights reserved

* Corresponding author E-mail address: ishm@inbox.ru ORCID: 0000-0001-5008-0721 (Mukhametzyanov)

This work is licensed under a Creative Commons Attribution-NonCommercial 4.0 International License (CC BY-NC 4.0). 


\section{Introduction}

In modern world, education continues to be the basis of personal and professional success. Transition from knowledge-type to the competency-based model of education changed the requirements for education. Now the graduate student should be able to use information resources productively and employ a wide range of information technologies to solve professional tasks. Undoubtedly, this cannot be achieved within the traditional organization of learning process in the framework of Educational Organization (EO). A broad and effective system of integrating modern ICT (information and communication technologies) into learning process is necessary also involving additional knowledge resources for promoting and deepening professional communication and providing a new level of continuous professional education.

In addition to the direct negative impact on health of the user due to violation of sanitary standards, it is necessary to mention the indirect negative influence that appears years later. ICT eliminates existing restrictions on the education of persons with special educational needs. This requires the adaptation of the educational environment to the health indicators of students (visually impaired, etc.) as the main difficulties in their educational process are caused by teachers no longer being the only source of knowledge, while the method of transmission - linear and dosed, does not suit students with different educational capacities.

With approval of the priority project "Modern digital educational environment in the Russian Federation", activities focused on digitalization of educational system are becoming ever more relevant.

\section{Materials and Methods}

In the framework of this study, we examined a number of scientific publications that allow us to determine trends in the development of the subject matter to establish the further direction of research.

\section{Results}

Under such circumstances, it becomes undoubtedly important to cultivate information culture (IC) among students, a code of rights and duties within the EO framework. In this case, it is essential to help students form sense of responsibility and legal culture, skills and responsibility for their own security, and safety of their personal data (Polyakov, 2016). 
In addition, these skills act as an invariant component of information training aimed at formation of IC of a person (Simonova et al., 2012).

For students, new goals and values of education - its individualization, creation of conditions for development of student's personality, open access to educational interactions, integration into global educational community should be of prime priority (Noskova et al., 2012).

\section{Discussion}

Modern student is trained in distributed educational environment, this determines the importance of organization of a health-protecting environment, especially outside the EO framework. Learning the rules of organization of activities outside of EO framework is the main condition for the effectiveness of training and preservation of student's health; it is also the condition for practical application of acquired knowledge — with emphasis on professional requirements and health restraints.

The structure of the health-protecting Digital Educational Environment (DEE) consists of following elements.

Complexity - inclusion in the environment of a variety of technical means (TM) and communication technologies, electronic educational resources (E-Learning Resources, ELR), and knowledge management systems. However, ELR itself should not only undergo a psychological and pedagogical expertise but be represented in accordance with current regulatory enactments to prevent a possible negative impact on health of the students (Mukhametzyanov, 2016). In terms of health protection, these are specialized programs for monitoring the duration of work with the communication devices, illumination intensity control, desktop adaptation to the student capabilities, etc.; and special TM for people with disabilities (hearing, vision, musculoskeletal etc.) (Mukhametzyanov, Mochalov, 2012).

Interactivity - integration of the entire data set in the students' access point to the DEE, providing training in accordance with the current standards with integration of additional distributed educational resources, visualization of health-protecting methods, physical training practices, nutrition, labor and recreation, and other in combination with remote control indicators of the physical state of the students.

Personal orientation within the DEE framework with respect to the polyenvironmental approach (class-lesson and thematic system, consideration of needs and capabilities of the student, etc.) and features of students' health indicators. 
Intellectualization - by means of not only the introduction of ICT in the educational process, but also the improvement of the corresponding advanced scientific and methodological support of the educational process. Such approach allows achieving the optimal level of development of the educational program without regulatory restrictions (by age, time, location, etc.) for the duration of training, and the student becomes an active participant of the educational process.

Another health-protecting element is formation of a personalized model of organization and activities in a person-oriented and secure DEE through formation of DEE-using culture and introduction to the legal culture in ICT, protection of information and personal data, information filtering skills. A significant aspect of such model is the possible integration of elements of positive socialization. Given that ICT is now becoming a priority factor in socialization of the individual, formation of IC and a "normal" socialization model (from social-medium point of view) becomes a dominant factor in the activity of the education system.

In this regard, it is essential to note the importance of ICT for traditional interpersonal communication through the utilization of its virtual component. In these conditions, formation of a personal DEE makes it possible to create a student's educational trajectory, considering his/her personal features and goals of personal development. ICT at this point allows not only to shape this environment, but also to ensure an effective and supervised activity of the student within the given environment, with respect to student's motivation, existing and formed attitudes and personal level of educational activity. Presenting the results of such activities within this environmental framework allows the student to correlate the level of personal educational tasks and needs with other peers, both within and outside the EO framework. The transmission of new knowledge personally acquired beyond the traditional educational environment within the framework of the EO allows the student to accept the new role of a creator and conductor of knowledge - which affects his/her self-esteem and the level of educational claims. It is also important that the DEE allows for the top clarity of the specific knowledge development with the possibility of reversibility of information and the right for mistake. In turn, reversibility allows assessing the degree of achievement within the goals and objectives of educational process.

Health-protecting aspects can be conditionally divided into: medical, sanitaryand-hygienic, organizational-methodical, and rehabilitation.

Speaking of DEE outside EO framework, it must be mentioned that healthprotecting aspects in this case are based on the principles of generalization of education, 
its natural suitability, positive motivation and a favorable emotional climate in teaching with principles of developmental learning. All of that is virtually impossible without an effective system of measures aimed at prevention of main educational risk factors (overload, stress, etc.); without methods of teaching students the ways of most effective educational activities; use of electronic and game-based learning aids; individuallyoriented homework assignments; methods for calculating educational assignment with respect to time spending for EO external educational activities.

It is also necessary to consider the difference in elements of the DEE of the EO from its elements outside of the EO framework. Perhaps the inconsistency of TM used (operating systems, application packages, etc.) might get revealed. It is quite often, when additional software products are needed to implement communication; and means of personalizing communication corresponding to student's health condition. It is of immediate interest for people with limited educational opportunities (reduced vision and hearing, disorders of the musculoskeletal system, etc.). An additional negative factor is violation of usage mode of TM of communication - with going against the recommended sanitary-and-hygienic standards and TM in terms of topical training, not during a specific lesson. An additional point is that the control functions are assigned to the student's parents - who may not have special training in terms of technical, ergonomic and sanitary-and-hygienic support for conditions of educational activity and monitoring the results. It should also be noted that often the overall level of parents' ICT competence is lower than students'. Unlike conditions of the EO, in the DEE at place of students' residence or stay - a selection of environment components (software, computer games, development and information programs) is assigned to persons without appropriate training (parents or students themselves) and is often determined by financial capabilities of the family. The resulting heterogeneity of TM within the framework of a single DEE makes it difficult to use unified ELR. Creation of ELR, as a rule, is guided by the teacher and the FGOS-standards, not by the student. This does not allow ELR to be used within the topical training framework and in independent learning outside the EO, which leads to complexity of monitoring training outcomes and reduces educational effectiveness.

Another factor reducing educational effectiveness of DEE outside the EO is a decrease of student's motivation in his/her natural condition - such as a place of residence that is not learning-oriented. It is also possible to use TM of DEE for noneducational purposes - which cause increased fatigue and impossibility to effectively perform educational activities. 
Considering the structure of the DEE in terms of health protection, it should be noted that it is necessary to meet its current sanitary-and-hygienic standards to organize and conduct the learning process. Sanitary-and-hygienic aspects can be related to the infrastructure of the educational process; they can be determined by changes in student's health condition during the learning process.

The medical aspects are:

- general, in terms of organization of medical provision for students;

- structure and organization of sanitary-and-hygienic support of the educational process;

- some aspects in the field of teachers' qualification on the issues of health preservation and development;

- commitment to currently utilized health-protecting technologies in the DEE structure to achieve a measurable result in terms of:

- content filtering skills, regulation of duration of continuous use of TM, adaptation to learning conditions outside the EO framework with respect to individual health indicators (visually or hearing impaired, etc.);

- adaptation for non-EO TM and availability of educational feedback;

- creation and utilization of ELR in accordance with the current regulations (psychological, pedagogical, ergonomic and other) on security of information in publications of educational purposes;

- availability of means (adequate to the age and level of student's intellectual capabilities development) for protecting health information from unauthorized use.

The DEE health-protecting aspects outside the EO framework are particularly interesting. This segment until now cannot be regulated. Its structure, safety, and health-protecting characteristics are determined by the student's personal regulation his/her level of IC, level of EO's awareness-raising activity in student's daily activity in the framework of modern DEE.

Several grounds for DEE framework outside EO include organization of the educational environment with consideration of student's age — which is not possible within the framework of the EO. TM of educational process are selected with respect to student's distinctions (peculiarities of his/her educational needs). It should be borne in mind that often these are portable electronic devices (smartphones, tablets, etc.) that can not only serve as an intermediary in accessing the DEE, but also perform independent medical functions - integrating the student into the environment, influencing the state of his/her psyche, lowering anxiety and possible negative impact on the student's 
psyche (Firth et al., 2017). The most complicated aspects are: observance of the work and rest schedule without external regulation; correspondence of the students' place of residence to current sanitary standards; lack of a methodology for evaluating the effectiveness of educational activities outside the EO framework (with respect to the student's distinctions). The problem of parental control is internationally relevant. At this point, parents' education is crucial - in ICT and in control of educational results, educational resources, information security tools, and so on, - in children's communications with modern ICT. Assigning this solely to teachers is incompetent, since educational process in the DEE is implemented to a greater extent outside the EO framework (Stanley et al., 2017).

Additional difficulties are: lack of a well-developed methodology for parents' training in terms of organizing a safe health-protecting DEE outside the EO; lack of a methodology for assessing the impact of ICT tools on the student outside the EO; lack of a methodology for monitoring health-protecting activities of the student and their immediate family members outside the EO. Consideration of these issues in traditional parent-teacher conferences does not affect the level of parents' education in the field of ICT; although it helps to outline the range of issues they are interested in.

Within the existing seven models of education quality (goal, resource, process, satisfaction, legitimacy, absence of problems, and organizational learning models), we consider it necessary to add another one that includes organizational and managerial components of health preservation, taking into account student's workplace design, content of training and educational methods used to preserve and develop the health of students during the schooling time.

We consider this to be fundamental in the context of computerization of education and its actual exit into an uncontrolled educational environment. For students with different health conditions, specialized ELR are needed in terms of content and presentation. Measuring materials in assessment of knowledge are also different.

In fact, it is a question of the possibility of implementing differentiated education within the framework of one micro-social community of students, grouped according to the formal sign of learning in the same EO and having a completely different level of mental, physical and social well-being, i. e. a question on possibility of creating a multi-level educational training within the framework of a single DEE and maximizing activation of education. To date, only the DEE makes it possible to implement this opportunity, and a teacher's role shifts to a facilitator's role. They create several DEEs in one, focused on an active learning strategy. DEE includes a safe physical 
environment, accessible ELR, justification of the teacher in terms of an independent evaluation of educational outcomes, effectiveness of managing individual educational trajectories within the framework of single DEE, development of academic mobility of students, their self-development and accomplishment of the educational needs with respect to the health condition and the nature of subsequent professional engagement (Davenport et al., 2019).

The DEE conditions allow several various projects, even within the framework of a class-lesson system. DEE can also establish horizontal communications between students who are not physically present within the formalized DEE. In this case - when they are co-educated, knowledge is gained during joint learning activities, when the students try to comprehend and apply different theories and concepts. Such cooperation between students in co-educational groups increases their motivation and optimizes the achievement of pedagogical and didactic learning goals. Students are responsible for educating each other and themselves. Studying in groups, they complement each other's knowledge; and learn to work in a team and resolve conflicts (Edwards, 2015).

In terms of differentiation according to ability, there is no need to separate them into different groups, and the separation takes place according to levels of the educational content availability and the methods of its delivery to the student. Whereby, connections between students of different educational potentials and health conditions remain in some cases, under conditions of the DEE, one does not need to pay attention to the nature of the medical condition (infectious, constituting a public danger or other) because there is no direct contact between students, the learning process takes place in virtual space. Still, the student's (particularly, in childhood age) developmental possibilities remain, since a habitual for a child/teenager situation of gamification and leveled activity is formed - after passing one level, student goes to the next, and so on (Vagramenko, Yalamov, 2015; Varenina, 2014; Morford, 2014).

An additional positive factor may be that students with different health conditions do not adapt to the conditions of learning and progress within the EO framework, but vice versa - the learning conditions themselves (ELR, distributed interactive resources of different levels, students' social communities, etc.) are being adapted to the student. It is undoubtedly impossible to imagine the same within the framework of traditional EO. Under these conditions, an integrated component of education is implemented namely, full inclusion. In several cases, when differentiating by health condition, the content of training is determined based on the limitations of the student's upcoming professional activities. An increasing number of students are unable to perform certain 
professional activities due to their health. And that obliges the teacher to save them from the excessive content of education insofar as it concerns the occupation that was not initially realized. In the formation of micro-groups within the society of students at different educational levels, there is a differentiation in terms of interests, which makes optimization of education with transition into gamification conditions, which intensifies subjective activity without deriving the student from existing reality (Buckley, Doyle, 2016).

Alongside, gamification allows deeper assessment of students' competencies and contextual application of obtained knowledge; and evaluation of strengths and weaknesses of students at different stages of problem solving. In fact, gamification allows use of game thinking skills for solving specific tasks (Huwer et al., 2018).

Utilization of ELR, their virtual components and gamification allows not only uniting and motivating the students to solve a common problem in an understandable form of activity, but also tracking the progress in achieving the goal and communication within this process (Zhang et al. 2017).

\section{Conclusion}

Along with transition from traditional physical learning environment to a virtual one and formation of DEE, the environment for preservation and development of student's health also changes. Herewith, even more important is regulation of external access to this environment, since this is not just personal data, but elements of building the physical, mental and social well-being of a person. The impact on these matters, its modification, calls into question the very survival of a person. At once, changing the learning process in terms of gamification and multi-level integration allows real inclusive education to be implemented in the health-protecting conditions of DEE.

\section{References}

Buckley, P., Doyle, E. (2016). Gamification and student motivation. In Interactive Learning Environments, 24(6), 1162-1175. DOI: 10.1080/10494820.2014.964263.

Davenport, J.L., Kao, V.S., Matlen, B.J., Schneider, S.A. (2019). Cognition Research in Practice: Engineering and Evaluating a Middle School Math Curriculum. In The Journal of Experimental Education, 1-20. DOI: 10.1080/00220973.2019.1619067.

Edwards, S. (2015). Active Learning in the Middle Grades. In Middle School Journal, 46(5), 26-32, DOI: 10.1080/00940771.2015.11461922. 
Firth, J., Torous J., Nicholas, J., Carney, R., Rosenbaum, S., Sarris, J. (2017). Can smartphone mental health interventions reduce symptoms of anxiety? A metaanalysis of randomized controlled trials. In Journal of Affective Disorders, 218, 15-22. DOI:10.1016/j.jad.2017.04.046.

Huwer, J., Bock, A., Seibert, J. (2018). The School Book 4.0: The Multitouch Learning Book as a Learning. In Companion.American Journal of Educational Research, 6(6), 763-772. DOI: 10.12691/education-6-6-27.

Morford, Z.H., Witts, B.N., Killingsworth, K.J., Alavosius, M.P. (2014). Gamification: The Intersection between Behavior Analysis and Game Design Technologies. In Behav Anal. 37(1), 25-40. DOI: 10.1007/s40614-014-0006-1.

Mukhametzyanov, I. Sh. (2016). Fiziologo-gigienicheskie trebovaniya k pedagogicheskoj produkcii, realizovannoj na baze informacionny’x i kommunikacionny’x texnologij [Physiological-hygienic requirements for pedagogical products realized on the basis of information and communication technologies]. In Computerization of Education and Science, 1(29), 3-15. Available at: https://elibrary.ru/item.asp?id=25014318

Mukhametzyanov, I. Sh., Mochalov, A.V. (2012). Rabochee mesto invalida vo vzaimodejstvii s personal'ny'm komp'yuterom [The workplace with a personal computer of a handicapped person: sanitary-and-hygienic and organizational aspects]. In Kazan Pedagogical Journal, 3, 141-150. Available at: https://elibrary.ru/item. asp?id=18987398

Noskova, T.N., Tumaleva, E.A., Shilova, O.N. (2012), Informacionny`e texnologii v obrazovanii ivy`sokotexnologichnaya obrazovatel ’naya sreda[Information technologies in education and high-tech educational environment]. In Universum: Bulletin of The Herzen State Pedagogical University, 2, 83-87. Available at: https://elibrary.ru/item. asp?id=19406307.

Polyakov, V.P. (2016). Pedagogicheskoe soprovozhdenie aspektov informacionnoj bezopasnosti $\mathrm{v}$ informacionnoj podgotovke studentov vuzov [Pedagogical support of the aspects of information security in the information training of students of universities]. In Pedagogical Informatics, 4, 37-47. Available at: https://elibrary.ru/ item.asp?id=27509540

Simonova, I.V., Bocharov, M.I., Kozlov, O.A. (2012). Principy' proektirovaniya metodicheskoj sistemy' obucheniya studentov informacionnoj bezopasnosti [Principles of designing a methodical system for training students in information security]. In Informatics and education, 7, 78-82. Available at: https://elibrary.ru/item. asp?id=18251013 
Stanley, J.L., Vaterlaus, J.M., Tulane, S., Beckert, T.E. A (2017). Place for Technology in Parent Education: An Exploratory Study of Parent Perceptions. In Marriage \& Family Review, 53:8, 811-825, DOI: 10.1080/01494929.2017.1359813.

Vagramenko, Y.A., Yalamov, G.Y. (2015). Kollektivnaya uchebnaya deyatel 'nost' uchashhixsyavsetevojinformacionno-obrazovatel nojsrede [Students teameducational activity in the network of information and educational environment]. In Pedagogical Informatics, 3, 42-51. Available at: https://elibrary.ru/item.asp?id=24365659

Varenina, L.P. (2014). Gejmifikaciya v obrazovanii [Gamification in education]. In ICOM, 6(2), 314-317. Available at: https://elibrary.ru/item.asp?id=22981456

Zhang, B., Robb, N., Eyerman, J., Goodman, L. (2017). Virtual Worlds and Gamification to Increase Integration of International Students in Higher Education: An Inclusive Design Approach. In The International Journal of E-Learning \& Distance Education, 32 (2), 1-21. Available at: http://www.ijede.ca/index.php/jde/article/ view/1057

\title{
Цифровое образовательное пространство. Здоровьесберегающие аспекты
}

\author{
И.Ш. Мухаметзянов \\ Институт стратегии развития образования \\ Российской академии образования \\ Россия, 105062, Москва, ул. Макаренко, 5/16
}

Приоритетный проект "Современная ичифровая образовательная среда в Российской Федерации” направлен на широкое внедрение современных ИКТ в образовательную систему. В то же время наблюдается заметный дисбаланс между количеством обучаемых, использующих современные технологии, и количеством преподавателей, готовых проводить такое обучение. Только 16 \% последних готовы создавать и использовать цифровые ресурсы в образовательных иелях. Кроме того, зачастую оченивается только иифровая среда образовательной организации, хотя в ицифровом образовании фактическое обучение также происходит вне ее. Мы попытались оценить текущую ситуачию реализации прочесса обучения в высокотехнологичной информационнообразовательной среде, включая образовательную организацию и место жительства или пребывания обучаемых, поскольку такая среда, вероятно, влияет на их здоровье, но только она позволяет осуществлять учебный процесс с учетом его состояния. Несмотря на это доступность цифрровых образовательных ресурсов не гарантирует успеха. Наличие у родителей навыков использования технологий для контроля образовательного прочесса и поддержания информационной безопасности и защиты персональных данных обучаемых вне образовательной организации является необходимым. 
Результаты исследования могут служить основой для развития программы по формированию ичифрового образовательного пространства обучаемых с учетом спеиифики образовательной организации, места пребывания и уровня информационной грамотности всех участников образовательного процесса.

Ключевые слова: ичифровое образовательное пространство, инклюзивное образование, здоровьесберегающее информационно-образовательное пространство.

Научная специальность: 13.00.00 - педагогические науки. 